\title{
The Effect of Organizational Culture and Personality on Organizational Citizenship Behavior mediated by Organizational Commitment on the Employees of PT Bank Tabungan Negara (Persero) Tbk Jember
}

\author{
Ida Nur Kholisah", Sampeadi, Markus Apriono \\ Department of Management, Faculty of Economics and Business, University of Jember \\ Jln. Kalimantan 37, Jember 68121 \\ E-mail: pidanurkholisah13@gmail.com
}

\begin{abstract}
This study aims to examine and analyze the effect of organizational culture and personality on organizational citizenship behavior mediated by organizational commitment on the employees of PT. Bank Tabungan Negara (Persero) Tbk Jember. This is a descriptive explanatory research. The population was all employees of PT. Bank Tabungan Negara (Persero) Tbk Jember with the sample consisted of 98 respondents taken by census sampling. Research data were analyzed using path analysis. Results showed that organizational culture and personality have a significant and positive effect on organizational commitment, organizational culture and personality have a significant and positive effect on organizational citizenship behavior, and organizational commitment has a significant and positive effect on organizational citizenship behavior of the employees of PT. Bank Tabungan Negara (Persero) Tbk Jember. These results imply that good organizational culture and personality can improve organizational citizenship behavior, directly, or indirectly as mediated by organizational commitment.
\end{abstract}

Keywords: Organizational Citizenship Behavior, Organizational Culture, Organizational Commitment, Personality.

\section{Introduction}

The globalization era generates various phenomenon in the field of human resources management. Every company has to attentively focus on human resources as the important and influential asset to increase company performance in the long-term. Human resource is a capital or assets for any organizations that plays a significant role as the planner and the driver to achieve all organizational goals. Therefore, every company must have high-quality human resources or employees as the key of success to run the whole operational system. The employees' quality of work is reflected on their work-behavior. A good work behavior reflects a good performance.

According to Titisari (2014), good-employees tend to present an extra-role performance, or known as Organization Citizenship Behavior (OCB), on their work environment that will finally help company achieving its best organizational performance. Organ (2014:43-72) explained that OCB is a form of behavior where individual choices and initiatives are not related to the organization's formal reward system, but indirectly enhances the effectiveness of organization. OCB can be created from several factors, e.g., organizational culture, personality, and organizational commitment. A good organizational culture supported by employee with good personality will create a high organizational commitment that, indirectly, leads the employees to have an extra role work or known as OCB. This condition will create an optimal employee performance.

A good organizational culture will affect organizational effectiveness. According to Robbins (2001), organizational culture is a shared-perception or a shared-value system embraced and appreciated by all members of the organization. Organizational culture has a strong impact on employee behavior that will lead to organization effectiveness supporting top management in understanding the organization that they are not only working based on policies and procedures, but, it is also about how to understand human behavior and empowering human resources in the best possible way (Khan and Rashid, 2012).

In addition to organizational culture, a good personality, as the indication of $\mathrm{OCB}$, is very important for organizational effectiveness. Essentially, personality is an attitude that every person has as a background for their behavior that embedded genetically and affected by enviromental factors (Ivancevich et al., 2006). Personality is inherent every individual and that it is difficult to be changed, so that it has a more stable influence on OCB. Employees with a positive personality will influence the process of creating company sustainability. Having a positive personality will directly create OCB.

In addition to organizational culture and personality, the focus of this research is examining organizational commitment as a mediator on creating OCB in the company. Employee commitment to their organization will create an organizational effectiveness. Generally, organizational commitment is an emotional attachment, identification, and involvement of individual with the organization and the tendency to stay as the member of the organization which is manifested in some attitudes such as loyalty and willingness to work optimally to reach the goals of the organization (Greenberg et al., 2003:160). Organizational commitment can affect the attitude of OCB. An employee with a high organizational commitment will direct all of his capabilities in order to reach organizational goals.

Many studies have explored the importance of OCB for an organization. Khan and Rashid (2012) stated that organizational commitment has the most positive and significant effect on OCB as compared to other variables. Organizational commitment is a good mediating variable to find out the relationship between variables affected the OCB. A study by Pratiwi (2013) mentioned that the organizational

* Corresponding author 
culture has a significant positive effect on OCB and organizational commitment, while organizational commitment as an intervening variable also has a significant positive effect on OCB. Sambung (2014) said that personality has a significant effect on organizational commitment and OCB. But, commitment has no significant-effect on OCB. Usmany et al. (2016) said that there is a significant positive influence of organizational culture on organizational commitment. Wijaya and Yuniawan (2017) proved that organizational culture has a significant positive effect on organizational-commitment and $\mathrm{OCB}$, and organizational commitment has a significant positive effect on OCB. A study by Aussy and Sudarma (2017) showed that personality has a significant positive effect on organizational commitment and $\mathrm{OCB}$, and organizational commitment has a significant-positive effect on OCB.

According to previous explanations, this research formulates the following problems: (1) does organizational culture significantly influence the organizational commitment of the employees of PT. Bank Tabungan Negara (Persero) Tbk (BTN) Jember? (2) does personality significantly influence organizational commitment of the employees of BTN Jember? (3) does organizational culture significantly influence the OCB of the employees of BTN Jember? (4) does personality significantly influence the OCB of the employees of BTN Jember? (5) does organizational commitment significantly influence the OCB of the employees of BTN Jember?.

\section{Method}

\section{Research Design}

This research a descriptive explanatory research. Descriptive research aims to obtain an overview of the parameters that measured from the conditions and indicator of variables, including organizational culture, personality, organizational commitment, and OCB. Explanatory research aims to explain the relationship between variables of the research by testing the formulated hypotheses.

\section{Data Type and Source}

This research used quantitative data analyzed using statistical calculation technique. Primary data were obtained from the results of questionnaires distribution.

\section{Population and Sample}

The population of this research was all employees of BTN Jember that consisted of 98 people. The sampling method used was census sampling as the number of the population was less than 100 people. Thus, the research respondents were all members of the population, i.e., 98 people.

\section{Data Analysis Method}

This research used path analysis to as the method to analyze research data. According to Sarwono (2006:147), path analysis is part of the regression analysis which used in analyzing the relationship between dependent variables, either directly or indirectly, through one or more mediating variables.

\section{Results and Discussions}

\section{Results}

Characteristics of Respondents
Characteristics of the respondents of this research is segmented based on gender, age, education, and tenure. Based on gender, the number of male respondents were 62 people $(63.27 \%$ ), while female respondents were 36 people $(36.73 \%)$. Based on age, the number of respondents aged 2130 years old were 40 people $(40.8 \%)$, aged $31-40$ years old were 28 people $(28.5 \%)$, aged $41-50$ years old were 22 people $(22.4 \%)$, and aged 51-60 years old were 8 people (8.1\%). Based on education, the number of $22(22.44 \%)$ respondents were high school graduates, $16(16.32 \%)$ respondents were diploma graduates, and 60 (54.1\%) respondents hold bachelor degree, 7 (7.14\%) respondents hold master degree. Based on tenure or the length of time working in the company, 24 people $(24.4 \%)$ had $1-5$ years of service, 54 people $(55.1 \%)$. had 6-10 years of service, 16 people $(16.32 \%)$ had $11-15$ years of service 4 people $(4.08 \%)$ had more than 15 years of service.

\section{Results of Data Analysis}

\section{Validity Test}

Validity test is used to measure the validity of a questionnaire. A questionnaire is valid if the statement on questionnaire was able to reveal something that will be measured by the questionnaire (Ghozali, 2012). The validity test in this research was carried out referring to the Pearson Product Moment method with significance level of 0.05 . The results of validity test are as follows:

Table 5. Results of Validity Test

\begin{tabular}{lccccc}
\hline \multicolumn{1}{c}{ Variable } & Item & $\mathrm{r}_{\text {table }}$ & $\mathrm{r}_{\text {statistics }}$ & Sig. & Result \\
\hline Organizational & $\mathrm{X}_{1.1}$ & 0.195 & 0.688 & 0.000 & Valid \\
Culture $\left(\mathrm{X}_{1}\right)$ & $\mathrm{X}_{1.2}$ & 0.195 & 0.813 & 0.000 & Valid \\
& $\mathrm{X}_{1.3}$ & 0.195 & 0.660 & 0.000 & Valid \\
& $\mathrm{X}_{1.4}$ & 0.195 & 0.729 & 0.000 & Valid \\
& $\mathrm{X}_{1.5}$ & 0.195 & 0.631 & 0.000 & Valid \\
& $\mathrm{X}_{1.6}$ & 0.195 & 0.675 & 0.000 & Valid \\
Personality & $\mathrm{X}_{1.7}$ & 0.195 & 0.711 & 0.000 & Valid \\
\cline { 2 - 6 } (X) & $\mathrm{X}_{2.1}$ & 0.195 & 0.785 & 0.000 & Valid \\
& $\mathrm{X}_{2.2}$ & 0.195 & 0.732 & 0.000 & Valid \\
& $\mathrm{X}_{2.3}$ & 0.195 & 0.607 & 0.000 & Valid \\
& $\mathrm{X}_{2.4}$ & 0.195 & 0.717 & 0.000 & Valid \\
Organizational & $\mathrm{X}_{2.5}$ & 0.195 & 0.695 & 0.000 & Valid \\
\cline { 2 - 6 } (Z) & $\mathrm{Z}_{\cdot 1}$ & 0.195 & 0.805 & 0.000 & Valid \\
& $\mathrm{Z}_{\cdot 2}$ & 0.195 & 0.776 & 0.000 & Valid \\
OCB (Y) & $\mathrm{Z}_{\cdot 3}$ & 0.195 & 0.750 & 0.000 & Valid \\
\cline { 2 - 6 } & $\mathrm{Y}_{\cdot 1}$ & 0.195 & 0.847 & 0.000 & Valid \\
& $\mathrm{Y}_{.2}$ & 0.195 & 0.736 & 0.000 & Valid \\
& $\mathrm{Y}_{.3}$ & 0.195 & 0.571 & 0.000 & Valid \\
& $\mathrm{Y}_{.4}$ & 0.195 & 0.734 & 0.000 & Valid \\
& $\mathrm{Y}_{.5}$ & 0.195 & 0.695 & 0.000 & Valid \\
\hline
\end{tabular}

Based on Table 5 above, it can be seen that the correlation between each indicator variable of organizational culture $\left(\mathrm{X}_{1}\right)$, personality $\left(\mathrm{X}_{2}\right)$, organizational-commitment $(\mathrm{Z})$, and OCB (Y) shows that the value of $r_{\text {statistics }}>r_{\text {table }}$ and sig. $<0.05$. Then, it can be concluded that all indicators in all variable are valid. 


\section{Reliability Test}

Reliability test is the stability level of a measuring-tool to measure a symptom or incident.

Table 6. Results of Reliability Test

\begin{tabular}{lccl}
\hline \multicolumn{1}{c}{ Variable } & $\begin{array}{c}\text { Cronbach's } \\
\text { Alpha }\end{array}$ & $\begin{array}{c}\text { Reliability } \\
\text { Standart }\end{array}$ & Result \\
\hline Organizational & 0.773 & 0.60 & Reliable \\
Culture $\left(\mathrm{X}_{1}\right)$ & 0.778 & 0.60 & Reliable \\
Personality $\left(\mathrm{X}_{2}\right)$ & 0.814 & 0.60 & Reliable \\
Organizational & 0.782 & 0.60 & Reliable \\
Commitment $(\mathrm{Z})$ & & \\
OCB (Y) & 0.75 &
\end{tabular}

Table 6 shows the results of reliability test between each indicator of the variable with Cronbach's Alpha values above 0. 60. These results prove that the research instrument was reliable.

\section{Normality Data Test}

Normality data test in a regression model aims to test whether an interfering variable or residual has a normal distribution or not.

Table 7. Results of Normality-Data Test

\begin{tabular}{lcc}
\hline \multicolumn{1}{c}{ Variable } & $\begin{array}{c}\text { Value of } \\
\text { Kolmogorov } \\
\text { Smirnov }\end{array}$ & Result \\
\hline $\begin{array}{l}\text { Organizational } \\
\text { Culture (1) }\end{array}$ & 0.134 & Normally distributed \\
$\begin{array}{l}\text { Personality (2) } \\
\text { Organizational }\end{array}$ & 0.149 & $\begin{array}{l}\text { Normally distributed } \\
\text { Commitment (Z) }\end{array}$ \\
OCB (Y) & 0.132 & Normally distributed \\
\hline
\end{tabular}

Based on Table 7 above, it can be seen that the value of probability or significance of the research variables is greater than 0.05 . Thus, it can be stated that data in this research are normally distributed.

\section{Path Analysis}

This research used path analysis that aims to examine the effect of organizational culture $\left(\mathrm{X}_{1}\right)$ and personality $\left(\mathrm{X}_{2}\right)$ on OCB (Y) through organizational commitment (Z). The followings are the results of path analysis:

Table 8. Results of Path Analysis

\begin{tabular}{|c|c|c|c|c|}
\hline \multicolumn{2}{|c|}{ Standardized } & \multirow{2}{*}{ Sig. } & \multirow{2}{*}{ A } & \multirow{2}{*}{ Result } \\
\hline Path & Beta & & & \\
\hline $\mathrm{X}_{1} \longrightarrow \mathrm{Z}$ & 0.163 & 0.001 & 0.05 & Significant \\
\hline $\mathrm{X}_{2} \longrightarrow \mathrm{Z}$ & 0.250 & 0.000 & 0.05 & Significant \\
\hline $\mathrm{X}_{1} \longrightarrow \mathrm{Y}$ & 0.237 & 0.010 & 0.05 & Significant \\
\hline $\mathrm{X}_{2} \longrightarrow \mathrm{Y}$ & 0.307 & 0.013 & 0.05 & Significant \\
\hline $\mathrm{Z} \longrightarrow \mathrm{Y}$ & 0.456 & 0.016 & 0.05 & Significant \\
\hline
\end{tabular}

Based on Table 8, results of the path analysis model equation are obtained as follows:

$\mathrm{Z}=0.163 \mathrm{X}_{1} \mathrm{Z}+0.250 \mathrm{X}_{2} \mathrm{Z}+\mathrm{e}_{1 . . .}$ (Equation 1)

$\mathrm{Y}=0.237 \mathrm{X}_{1} \mathrm{Y}+0.307 \mathrm{X}_{2} \mathrm{Y}+0.456 \mathrm{ZY}+\mathrm{e}_{2} \ldots$ (Equation 2)

\section{Hypotesis Testing}

T Test

$\mathrm{T}$ test is used to find out the influence of one explanatory variable, individually, in explaining the variation of dependent variable (Kuncoro, 2007). The significance level used in this research is 0.05 .

Table 9. Results of T Test

\begin{tabular}{ccc}
\hline Variable & $\mathrm{A}$ & Sig \\
\hline $\mathrm{X}_{1} \longrightarrow \mathrm{Z}$ & 0.05 & 0.001 \\
$\mathrm{X}_{2} \longrightarrow \mathrm{Z}$ & 0.05 & 0.000 \\
$\mathrm{X}_{1} \longrightarrow \mathrm{Y}$ & 0.05 & 0.010 \\
$\mathrm{X}_{2} \longrightarrow \mathrm{Y}$ & 0.05 & 0.013 \\
$\mathrm{Z} \longrightarrow \mathrm{Y}$ & 0.05 & 0.016 \\
\hline
\end{tabular}

Based on Table 9 above, it can be seen that the influences of each independent variable on dependent variable are as follows:

a. The significance level $(\alpha)$ of the organizational culture $\left(X_{1}\right)$ is $0.001<0.05$. It means that organizational culture has a significant effect on organizational commitment. Thus, $\mathrm{H}_{1}$ is accepted.

b. The level of significance $(\alpha)$ of personality variable (X2) is $0.000<0.05$. It means that personality has a significant effect on organizational-commitment. Thus, $\mathrm{H}_{2}$ is accepted.

c. The level of significance $(\alpha)$ of organizational-culture (X1) is $0.010<0.05$. It means that organizational culture has a significant effect on OCB. Thus, H3 is accepted.

d. The level of significance $(\alpha)$ of personality variable (X2) is $0.013<0.05$. It means that personality has a significant effect on OCB. Thus, $\mathrm{H}_{4}$ is accepted.

e. The level of significance $(\alpha)$ of organizational commitment $(Z)$ is $0.016<0.05$. It means that organizational commitment has a significant effect on OCB. Thus, $\mathrm{H}_{5}$ is accepted.

\section{Discussions}

\section{The Effect of Organizational Culture on Organizational Commitment}

The Effect of Organizational Culture on Organizational Commitment

The results of hypothesis testing show that organizational culture has a significant effect on organizational commitment. It indicates that the implemented organizational culture is as expected by the employee the will lead to a high organizationalcommitment. The coefficient of regression is positive which means that the better organizational culture, the better the organizational commitment. These results are strongly supported by respondents' answers related to organizational culture and organizational commitment variables. Most of respondents were agreed to 7 indicators of the the organizational culture variable. Thus, this research concludes that organizational culture that applied by BTN Jember was good and appropriate.

Hofstede (2005:21) says that culture is the values, norms, and behavior of people who embrace these beliefs and cultures. Cultural values play a significant role in forming the habits and practices within an organization. Whereas, organizational 
commitment is an attitude that reflects employee loyalty to the organization and that it is a sustainable process which member of the organization can express their concern towards organization for the organization progress, success, and sustainability. The results of this research support previous research conducted by Usmany et al. (2016) stating that there is a significant positive influence of organizational culture onorganizational commitment.

\section{The Effect of Personality on Organizational Commitment}

The results of hypothesis testing show that personality affects organizational commitment. It indicates that personality of the employee is in line with the expectation that leads to a high organizational commitment. The relationship that shown by the coefficient of regression is positive. It means that the better the employee personality, the higher the organizational commitment. These results are reinforced by respondents' answers about personality and organizational commitment variables. Most respondents agreed to 5 indicators in the personality variable. Thus, we can conclude that all employees of BTN Jember have good personality at work.

Personality is any type of behavior which is distinctive and unique embeded in every individual. It is often to used as a natural reaction or a tool to adjust towards everything that happens around one self (Maramis et al., 2009; Setyonegoro et al., 2000). The results of this research in line with the results of the research by Roby Sambung (2014 proving that there is a significant influence of personality on organizational commitment.

\section{The Effect of Organizational Culture on OCB}

The results of hypothesis testing show that organizational culture has a significant effect on OCB. These results indicate that the implemented organizational culture is in line with employee expectations that will finally form a good OCB. The coefficient of regression is positive which means that a better organizational culture will increase OCB. These results are reinforced by respondent's answers which related to organizational culture and OCB variables. Most respondents answered strongly agree and agree towards the indicators.

One of the characteristics of organizational culture proposed by Robbins (2001:510-511) is orientation towards team or the level of work activity that is set in the team, not individually. Orientation towards team is very important for building OCB-behavior and it is based on a strong organizational culture. A firmly embeddedd organizational culture can affect a strong level of solidarity amongst the employees to achieve organizational goals. A strong organizational culture must be instilled in every employee (Titisari, 2014: 59). It will create OCB character of the employees towards the company. The results of this research supported a study by Pratiwi (2013) proving that organizational culture has a positive significant effect on OCB.

\section{The Effect of Personality on OCB}

The results of hypothesis testing show that the personality has a significant effect on OCB. This indicates that employee personality is as expected that will lead to the formation of a good OCB. The correlation showed by the regression coefficient is positive which means the the a better personality will increase OCB. These results are strengthened by the respondent answer related to the personality and OCB variables. Most of the respondents stated strongly agree and agreed. The personality factor is something that attached in every employee and that it is difficult to change so it will have a more stable on OCB. The employees who have positive personality will affect the process of creating company sustainability. The positive personality will directly create the OCB.

According to Organ (2014), individual differences are the predictor who plays the important role that will lead the employee to show their OCB. It is believed that some people who show who they truly are or the way they show their personality are more possible to show their OCB. The results of this research are in line with the results of a study by Aussy and Sudarma (2017) stating that personality has a positive and significant effect on OCB.

\section{The Effect of Organizational Commitment on OCB}

The results of hypothesis testing show that organizational commitment has a significant effect on OCB. This indicates that employees commitment is in accordance with company expectations that will form a good OCB. The correlation showed by the regression coefficient is positive, which means that the higher the organizational commitment the higher the OCB level. Those results were strengthened by the respondent answer related to organizational commitmen and OCB variables. Most of the respondents stated strongly agreed and agree towards the indicators mentioned in the questionnaire.

The organizational commitment is a confident attitude showed by the employees towards their organization where the employee feel that they are part of all company values, they will have high loyalty and ready to work hard to achieve the company goals. This organizational commitment will give better impact to the company as the increasing of OCB among the employees will reduce number of absences and lower the turnover level that will finally create a better organization climate. The OCB could reduce disputes and increase the job efficiency. Therefore, the OCB will help growing the positive things for the company in order to achieve goals or better company social life.

Results of this study supported Wijaya and Yuniawan (2017) stating that organizational commitment has a significant effect on OCB.

\section{Conclusion}

In general, this study concludes that organizational culture and personality have a significant and positive effect on organizational commitment, organizational culture and personality have a significant and positive effect on organizational citizenship behavior, and organizational commitment has a significant and positive effect on organizational citizenship behavior of the employees of PT. Bank Tabungan Negara (Persero) Tbk Jember. These results imply that good organizational culture and personality can improve organizational citizenship behavior, directly, or indirectly as mediated by organizational commitment. Further research could use other variables not mentioned in this study to find out other factors that affect OCB in an organization. 


\section{Thank You Note}

The author would like to say thank you to all employees of BTN Jember as the research respondents who have helped a lot during the research process.

\section{References}

Aussy, W. N. A., dan K. Sudarma. 2017. Pengaruh Person Organization Fit dan Personality pada Organizational Citizenship Behavior dengan Organizational Commitment sebagai Variabel Intervening pada Karyawan Hotel Kesambi Hijau Semarang. Management Analysis Journal. 6(3).

Ghozali, H. Imam 2012. Aplikasi Analisis Multivariate dengan Program IBM SPSS. Yogyakarta:Universitas Diponegoro

Greenberg, J., dan A. R. Baron. 2003. Behavior in Organization; Understanding and Managing the Human Side of Work. New Jersey: Pearson Education Inc.

Hofstede, G, dan G. J. Hofstede. 2005. Culture and Organizations Software of the Mind. McGraw-Hill.

Ivancevich, J. M., R. Konopaske, dan M. T. Matteson. 2007. Perilaku dan Manajemen Organisasi. Jakarta: Erlangga.

Khan, S. K., dan M. Z. A. Rashid. 2012. The Mediating Effect of Organizational Commitment in the Organizational Culture, Leadership and Organizational Justice Relationship with Organizational Citizenship Behavior. International Journal of Business and Social Science. 3(8).

Kuncoro, M. 2007. Metode Kuantitatif, Teori dan Aplikasi untuk Bisnis dan Ekonomi. Yogyakarta: UPP STIM YKPN.
Maramis, W. F., dan A. A. Maramis. 2009. Catatan Ilmu Kedokteran. Edisi Kedua. Surabaya: Airlangga University Press.

Organ, D. W. 2014. The Motivational Basis of Organizational Citizenship Behavior. In B.M Staw and L.L. Cummings: Research in Organizational Behavior. 12(43-72).

Pratiwi, I. (2013). Analisis Pengaruh Budaya Organisasi dan Keadilan Organisasi Tehadap Organizational Citizenship Behavior (OCB) dengan Komitmen Organisasional sebgai Variabel Intervening. Skripsi. Semarang: Fakultas Ekonomika dan Bisnis Universitas Diponegoro.

Robbins, S. P. 2001. Perilaku Organisasi, Konsep, kontroversi, aplikasi. Jakarta: PT Prenhalindo.

Sambung, R. 2014. Pengaruh Kepribadian terhadap Organizational Citizenship Behavior dengan Komitmen Organisasi sebagai Variabel Intervening. Jurnal Program Sarjana Fakultas Ekonomi Universitas Palangkaraya.

Sarwono, J. 2006. Metode Penelitian Kuantitatif dan Kualitatif. Yogyakarta: Graha ilmu.

Titisari, P. 2014. Peranan Organizational Citizenship Behavior (OCB) dalam Meningkatkan Kinerja Karyawan. Jakarta: Mitra Wacana Media.

Usmany, T. P., D. Hamid, dan H. N. Utami. 2016. Pengaruh Budaya Organisasi terhadap Komitmen Organisasi dan Kinerja Karyawan. Jurnal administrasi Bisnis. 37(2).

Wijaya, N. A., dan A. Yuniawan. (2017). Analisis Pengaruh Budaya Organisasi dan Dukungan Organisasi terhadap Organizational Citizenship Behavior dengan Komitmen Organisasi sebagai Variabel Intervening. Diponegoro Journal of Management. 6(4): 1-13. 